\title{
Popüler Suç Filmlerinin İdeolojisi: Kabadayı Filmi Örneği*
}

Makale Bilgileri /

Article Info:

Gönderim / Received: 04.03.2019

Kabul / Accepted: 23.07.2019

\footnotetext{
** Sorumlu Yazar /
} Corresponding Author:

Sivas Cumhuriyet Üniversitesi, Sivas, Türkiye ggultekin@cumhuriyet.edu.tr

\section{Gökhan Gülltekin** (D)}

Sivas Cumhuriyet Üniversitesi, İletişim Fakültesi, Radyo Televizyon ve Sinema Bölümü, Sivas, Türkiye

* Bu çalışmanın temeli, yazarın 12.12.2017 tarihinde Selçuk Üniversitesi Sosyal Bilimler Enstitüsü tarafindan kabul edilen, Türk ve Amerikan Popüler Sinemasında Suçun Estetiği adlı doktora tezindeki 'Suç Filmlerinin İdeolojisi' başlığına dayanmaktadır.

\section{$\ddot{O} \mathbf{z}$}

Toplumu ilgilendiren önemli olgulardan biri olarak suç, özellikle 1990 sonrası popüler filmler için oldukça kullanışlı bir temaya dönüşmüştür. Bugün pek çok popüler filmin konusu, suç ve ona bağlı şekilde ortaya çıkan şiddet, ceza, suçlu, kurban vb. olgu, olay ya da kişilerden oluşmaktadır. Türk sinemasında da durum farklı değildir. Suç ve suçludan yola çıkan Eşklya'nın (1996) gişe hasılatına heveslenen pek çok yapımcı, suçu satılacak popüler bir malzeme olarak görmüştür. 2000 sonrasında vizyona giren ve en çok gişe yapan filmler listesinde yer alan Çakallarla Dans, Kolpaçino, Maskeli Beşler, Organize İşler, Ali Baba ve 7 Cüceler, Sen Kimsin?, Yahşi Batı ve Muro'nun komediyi; New York'ta Beş Minare ya da Av Mevsimi'nin macera ve drami; Kurtlar Vadisi'nin ise politikayı suçla yoğurması, belki de seyircinin ve yapımcıların suç olgusuna ne kadar meraklı olduğunun en iyi kanıtıdır. Aynı listede bulunan Kabadayı'nın (2007) ise Eşkıya' ya benzer şekilde, suç ve suçludan hareketle öyküsünü yapılandırdığı görülmektedir. Asıl önemli olan ise, Kabadayı'da suç ve suçlular üzerinden din, aile, devlet ve toplum hakkında çeşitli gerçekliklerin yeniden üretildiğini görmeye çalışmaktır. Buna bağlı olarak, filmin öykü ve söylem çatısı altında hangi ideolojilerin, nasıl işlerlik kazandığını ortaya koymak çalışmanın amacını oluşturmaktadır. Bu amaç kapsamında çalışmada örneklem olarak belirlenen Kabadayı filmi ideolojik yöntem çerçevesinde çözümlenmiştir. Sonuç olarak, suç ve cezanın ötesinde din, aile, devlet ve toplum üzerine çeşitli ideolojilerin, filmin öykü ve söylem elemanları aracılığıyla yeniden üretildiği gözlemlenmiştir.

Anahtar Kelimeler: Suç, Popüler Türk Suç Filmleri, İdeoloji, Kabadayı. 


\section{Ideology of the Popular Crime Movies: Kabadayı Movie as An Exampler}

\section{Abstract}

As one of the important phenomena concerning society, crime has become quite an instrumental theme especially for the post-1990 popular movies. Today, the theme of a great number of movies is crime and phenomena, events or persons that are related to crime like violence, punishment, criminal, victim, etc. It is not so different for Turkish cinema as well. Many producers who desired to achieve the box office of Eşkıya (Yavuz Turgul, 1996) considered crime as a great material to sell. Movies that came to theatres after 2000 and managed to hit the list of most successful box office titles blend crime with different genres like comedy as in Çakallarla Dans, Kolpacino, Maskeli Beşler, Organize İşler, Ali Baba ve 7 Cüceler, Sen Kimsin?, Yahşi Batı and Muro; like drama as in New York'ta Beş Minare or Av Mevsimi and with politics as in Kurtlar Vadisi. This can be considered as a great sign that the audience and producers are highly fond of the concept of crime. The movie Kabadayl from the same list has a story that was built up based on the perspectives of crime and criminals similarly to Eşkıya. But the most important thing we have to see in Kabaday is that various realities of life like religion, family, government and society are being reproduced over crime and criminals. In parallel with this idea, the purpose of this study is to determine which ideologies are falling under this story and discourse framework, and how do they become effective. For that purpose, the movie Kabaday has been chosen as a sample and analyzed in terms of ideological method. As a result, beyond crime and punishment, various ideologies on religion, family, government and society is being reproduced through the story and discourse elements in the movie.

Keywords: Crime, Popular Turkish Crime Movies, Ideology, Kabadayl.

\section{Giriș}

Bilim, sanat, felsefe ya da hukuk ideolojik olarak doğar ve ideolojik olarak işlev görebilir (Therborn, 1989, s. 12). Bu açıdan bir sanat dalı olarak sinemanın da her şeyden önce ideolojik amaçlarla ortaya çıktığını düşünebilmek gerekir. İdeoloji içermeyen bir filmin varlığından söz etmek pek mümkün değildir. Comolli ve Narboni'nin vurguladığı gibi, bir film verili ekonomik ilişkiler içinde üretilen, kendine özgü ve emek gerektiren bir üründür. Ayrıca her ne şekilde olursa olsun ideolojiktir (2010, s. 99).

Sinema aracilı̆̆ıyla sunulan ideolojiler filmin türü, ülkesi, dönemi, bütçesi vb. pek çok öğeyi etkileyebilmektedir. Bu açıdan Ryan ve Kellner, Hollywood filmlerinin çoğunun ideolojik olduğu; fakat sadece belirli ideolojik kalıplarla değil, çekildiği tarihsel dönemin şartlarıyla da düşünülmesi gerektiğini belirtirler (2010, ss. 17,18). Yine Krutnik, Hollywood'un kısa dönemli hamlelerle, mevcut zamanın kültürel iklimini sermayesiyle birleştirerek, topluma uyumlu filmler ürettiğine vurgu yapar (2001, s. 11). Dolayısıyla aynı türde üretilen filmlerin farklı dönemlerde, farklı ideolojiler barındırması normaldir. Dahası, bir filmin devam serilerinde bile farklı ideolojiler işlendiğini görmek mümkündür. Bunun en iyi örneklerinden biri Rocky serisidir. Rocky I' de (John G. Avildsen, 1976), Rocky Balboa beyaz işçi sınıfını temsil ederek, gerçek hayatta bu sınıfa dâhil olan izleyicilerin sıkıntılarını hafifletir. Rocky IV (Sylvester Stallone, 1985) filminde ise Rocky Balboa -bir beden olarak- Rusya'nın şeytanlaştırıldığı bir öyküde bizzat Amerika'yı temsil ederek, sevilen tarafa yerleştirilir. Rusya'y1 temsil eden Ivan ise tam anlamiyla seyircinin nefret duyacağı bir noktaya konumlandırılır. Yani Ivan'a duyulan nefret, dolaylı olarak Rusya'ya hissedilmesi gereken duygu şeklinde kendini açığa çıkartır. Bedene karşı böyle bir bakış, Adorno ve Horkheimer'ın görüşlerine de oldukça uygun gözükmektedir. Onlara göre, bedene duyulan aşknefret, modern topluma tamamen işlemiştir (2010, s. 309).

Modern toplumlarda bedene karşı duyulan aşk ya da nefret, çeşitli ideolojik hamlelerle şekillendirilebilmektedir. Eğitim, din, aile gibi kurumlar ya da iletişim araçları ve sanat aracılığıyla ortaya koyulan ürün veya eserler, hangi bedene aşk, hangisine nefret beslenmesi gerektiğinin ideolojik pratiklerini sunar. Hatta aynı bedene hem aşk hem de nefret beslenmesi gerektiğine dair ideolojik hamleler gerçekleştirilebilir. Yani herhangi bir eylem ve onun eyleyenine karşı hem nefret, hem de aşk duyguları ortaya çıkabilir. Suç ve suçlu da 
böylesi bir aşk-nefret beraberliğinin eylem ve eyleyenidir.

Marks, suçlunun polis örgütünü, yargıçları, cellatları, hukuk profesörlerini ürettiğini belirtir. Ona göre, sadece bu tip meslekler üretilmekle kalmaz, bu meslektekilerin kullanacakları aletler de üretilir. Dahası, sadece işkence bile insan ruhunu ve zekâsını zorlayan ileri düzey mekanik icatlara neden olmuştur. Üretim sadece gerçek yaşamla da sınırlı değildir. Suçlu, Marks'a göre, toplumun ahlaki ve estetik duygularını harekete geçiren yapıdadır. Suçlu, sayısız sanat yapıtının üretilmesini sağlar, burjuva yaşamının güvenliğini ve tekdüzeliğini bozarak, ona bir dinamizm kazandırır, mülke yönelik eylemleriyle, yeni savunma yöntemlerinin ve yeni makinelerin icat edilmesinde etkilidir (1998, ss. 363,364). Özetle, kapitalizm suçu kendi yararına kullanmıştır. Bunu yaparken de sürekli bir sermaye birikiminin ve dolaşımının önünü açacak meslekler, icatlar ve ürünler üretmektedir. Dolayısıyla suç ve suçlu kapitalizm için oldukça ideolojik bir malzemedir. $\mathrm{Bu}$ açıdan Dönmezer'in vurguladığ 1 gibi, ideolojiler suça neden olabilir (1994, s. 71); fakat as1 önemlisi, suçun ideolojik amaçlar doğrultusunda kullanılmasıdır (Demirbaş, 2012, s. 272).

Suçun ideolojik amaçlarla kullanıldığı alanlardan biri de filmlerdir. Filmler, sunduklarını çekici hâle getirirken izleyicilere çeşitli ideolojileri ulaştırma ve onları bu ideolojilerin gerçekliğine inandırma gücüne sahiptir. Hâlâ yüzlerce suç filminin yapım aşamasında olduğunun duyurulması, suçun günümüz sinemasında belki de en sik kullanılan tema olduğunu kanttlar niteliktedir. Bu yoğunluk, suç türü filmler aracılığıyla yayılan ideolojilerin de gün geçtikçe yoğunlaşacağını, daha doğru bir ifadeyle, sinema aracılığıyla yayılan egemen ideolojilerin neredeyse sadece suç teması üzerinden işlerlik kazabileceğini göstermektedir.

Suç, her türdeki filme nüfuz etmiş olabilir; fakat genel anlamda, suçun western, gangster, polisiye ve dedektif, kara film veya yeni kara film türlerinde temele alındığı söylenebilir. Aksiyon ise tür değil, suç temelli filmlerde sıkça kullanılan bir tema olarak düşünülmelidir. Öte yandan, korku ya da bilimkurgu sinemasındaki eylemleri suç olarak görmek ya da algılamak, suçun doğasına ve yapısına uymaması açısından anlamsızdır. Benzer şekilde, gerilim ve suç filmleri her ne kadar akraba gibi görünseler de, bu iki tür arasında bazı farkl111klar bulunmaktadır. Gangster, soyguncu ya da dolandırıcı karakterin motivasyonu, gerilimin fail karakterinin motivasyonundan farklı işler. Daha da önemlisi Clarens'in belirttiği şekliyle, gerilim filminin suçlusu, kendini temsil ederken, suç filmlerindeki suçlu yasayı, toplumu ve bizzat kendisini (suçluyu) temsil eder. Yani suç filmleri, yasaların ihlali ile ihlale karşı verilecek ceza üzerinden işlerlik kazanır. Gerilim filminde ise suçlu Clarens'e göre, sadece kendini temsil etmektedir (1979, s. 13). Yine Benyahia'nun açıkladığ de suç teşkil eden eylemlerin var olduğunu düşünmek gerekir; fakat aralarında temel bir fark bulunmaktadır: Melodramlarda, ortada bir suç olsa da hukuk kuralları müdahalesini görmek olası değildir. Suç psikolojik ve kişisel nedenlerle işlenir ve aile sınırları içinde halledilmeye çalış1ır (2014, s. 125). Leitch, bu yönden suç filmi türünün en kullanışlı şekilde, 'suçu temele alan filmler' olarak düşünülmesi gerektiğini savunur. Bundan daha önemlisi, suç filmlerine sadece bir tür olarak değil, kültürel bir çalışma alanı olarak da bakılması gerektiğine değinir. $\mathrm{Bu}$ açıdan $\mathrm{o}$, suç filmlerini yeni kategoriler altında değerlendirmekten ziyade, kara film (film noir), gangster ya da suç komedileri gibi suç filmlerinin alt türlerinin, izleyiciye sunduklarına odaklanmanın daha doğru olduğuna vurgu yapar (2002, ss. 2-12). Leitch'in görüşüne uygun şekilde, bu çalışmanın amacı da popüler bir suç filmi olan Kabadayı'nın, suç ve cezanın yanı sıra din, devlet, aile ve toplum hakkında sunduğu ideolojilere odaklanmaktır. Bu amaç kapsamında öncelikle 'İdeoloji ve Sinema' ilişkisine değinmek anlamlı olacaktır.

\section{1. İdeoloji ve Sinema}

Francis Bacon ve Thomas Hobbes'un görüşlerine temellendirilen ideoloji kavramının ilk kullanımı Fransız Devrimi'nden sonraya rastlar. Bu açıdan Antoine Destutt de Tracy, Éléments d'Idéologie adlı eserinde yer verdiği 'idealogy' kavramıla fikirlerin doğuştan değil, fiziksel duyular 
aracılığıyla elde edildiğine vurgu yapmıştır. Ona göre, ideoloji 'zihin felsefesi' olarak görülmelidir (McLellan, 2012, s. 6). Yine Napoleon ideolojiyi her türlü eleştirel görüşle bir tutarken, Scott ideolojiyi 'egemen düşünceler' şeklinde değerlendirmiştir. $\mathrm{Bu}$ görüşlerden daha kabul edilebilir olanlar ise Marks ve Engels tarafindan ortaya atılmıştır (Williams, 2012, ss. 185-189). Onlara göre, maddî üretim araçlarına hükmeden sınıf, zihinsel üretim araçlarına da hükmeder. Dolayısıyla kendilerine zihinsel üretim araçları verilmeyenlerin düşünceleri, egemen sınıfın düşüncelerine tabi olmaktan kurtulamaz (Marks ve Engels, 2003, s. 50). Öte yandan, bu düşüncelerin hepsi ideolojik değildir. Bir fikrin ideolojik olabilmesi için, toplumdaki eşitsizlikleri ve çelişkileri gizlemesi gerekmektedir. Marks ve Engels'e göre, ideolojileri işçi sınıfı da üretebilir; fakat gerçek anlamda ideoloji, hâkim sınıfin düşünceleriyle anlam kazanan bir kavramdır (McLellan, 2012, s. 11).

İdeoloji hakkında ortaya koyulan temel düşünceler göz önüne alındığında, Marks ve Engels'in görüşlerinin kabul edilebilir olduğu söylenebilir. Onların ideoloji kavramı genel sinema pazarı açısından düşünüldüğünde, Hollywood filmlerinin egemen ideolojinin yayılması için oldukça etkili bir araç olduğu söylenebilir. $\mathrm{Bu}$ filmler için temelde seyircinin beklentisi ön plandaymış gibi görünse de, aslında egemen ideolojinin ne istediği önemlidir. Böylece egemen sistem, Hollywood filmleri aracılı̆̆ıyla kendi doğasını sergileme firsatı bulmaktadır. Bu yönden Kırel, sinema pazarının büyük kısmını elinde bulunduran Hollywood'un, erkek egemen düzeni destekleyen, kadınlara hak tanımayan, yasanın kurulmasını temel amaç edinen, bireysel başarı ve toprak sahipliğinin önemini kutsayan, Amerika'nın özgürlüğün koruyucusu olduğunu savunan $v b$. ideolojilerle yapılandığ 1 vurgulamaktadır (2012, s. 192). Öte yandan, Hollywood'un bazen egemen ideoloji destekçiliğinden uzaklaştığını da belirtmek gerekir. Hollywood filmleri bazen saldırgan, gerçekçi, somut veya eleştirel bakış açılarını da yansıtmıştır; fakat bunu sinemanın ticari açıdan daima bir gösteri olduğunu unutmadan, kabul edilebilir, anlaşılır ve izlenebilir şekilde gerçekleştirmiştir
(Scognamillo, 1997, s. 50). Her zaman izleyicilerin beklentilerine, toplumsal ve ekonomik durumlara göre hareket eden Hollywood filmleri, temelde 'Amerikanlaştırma' anlayışından hareketle, farklı ideolojik mesajlar üretmenin firsatını da yakalamaktadır. $\mathrm{Bu}$ filmler, düzene ait bilgiyi toplumsal temsillerin yeniden üretimiyle kodlayarak seyirciye sunar ve böylelikle toplumsal gerçekliği oluşturan kültürel sistem içindeki yerlerini alır. Seyircinin bu gerçekliği kabulü ise genelde içselleştirmeyle gerçekleşir (Ryan ve Kellner, 2010, s. 35).

Seyirci, filmler aracillğıyla kendisine sunulan ideolojileri benimseyebilmektedir; çünkü filmler sunduğu ideolojileri meşrulaştırma ve seyircinin egemen ideolojiye karşı hareketini kısıtlayabilme gücünü elinde bulundurur. $\mathrm{Bu}$ da seyircide 'yanlış bilinç' oluşmasına sebep olur. Yanlış bilinç, seyircinin gerçeği görmesini engellemekte ve mevcut ideolojinin doğal bir süreç gibi algılanarak içselleştirilmesini sağlamaktadır (Özden, 2004, s. 169-170). Filmler bunu kendi ideolojik yapıları aracılığıyla gerçekleştirir. $\mathrm{Bu}$ açıdan Monaco, filmlerin bir şekilde şu 3 düzeyde kendi politik doğasını sergilediğini vurgular (2010, s. 251):

- Ontolojik olarak; film, kültürün geleneklerini tahribata uğratır.

- Mimetik olarak; filmler gerçekliği yansitırlar ya da onu yeniden üretirler.

- İçsel olarak; filmlerin izleyiciyle ilişkisinde doğal bir politik mesaj iletimi bulunmaktadır.

Monaco, ontolojik açıdan özellikle filmsel kahramanın seyirci için önemine vurgu yapar. Mimetik açıdan ise gerçekliğin filmler aracılığıyla yeniden üretilebilir olduğunu belirtir. Filmler kamera, kurgu, karakter, zaman, mekân, 1şık, renk, ses ve müzik dinamikleri aracılığıyla gerçekliği yeniden üretir. $\mathrm{Bu}$ yeniden üretim Comolli ve Narboni'ye göre, egemen ideolojinin belirsiz, formüle edilmemiş, teorize edilmemiş ve düşünülmemiş dünyasının kaydıdır. Bu sebepten, film sürecinde 'şeyler' oldukları gibi değil, mevcut ideolojiler çerçevesinde yeniden şekillendirilerek perdeye yansitllır. Kullanılan nesneler, biçimler, şekiller, anlamlar, öyküler ve stiller, belli bir 
ideolojiye atıfta bulunmaktadır (2010, s. 101). Dolayısıyla film, kendini kendine sunan bir ideoloji olarak düşünülebilir. Gerçekliğin yeniden şekillendirilmesi, Ryan ve Kellner için de filmlerin ideolojik olduklarını kanıllar. Filmler bu ideolojik tavr1 biçimsel yapısı, anlatı tarzı, karakter özdeşleştirmesi, seyirciyi güdüleme, çerçeve uyumu gibi uygulamalar aracıllğıyla ortaya koymaktadır. Sonuçta ise filmsel imge ve söylemler seyirci tarafindan nesnel ve tarafsız gibi algilanır (2010, s. 18).

Filmler, seyirciye belli bir konumu ya da bakış acısını telkin eder. Biçimsel görenekler, filmin kurmaca yapısına dair işaretleri silerek, seyircinin sunulanı içselleştirmesine hizmet eder. Kahramanlık, melodram, suç ve şiddet öyküleri gibi tematik görenekler ise gerçekliği toplumsal değer ve kurumlarla ilişkilendirerek, seyirciyi sunulanların değişmez bir dünyanın doğal göstergeleri olduğuna inandırır. Böylece seyirci, toplumsal düzenin temel varsayımlarını benimsemeye ve bunların içerdiği akıldışıllk ve adaletsizlikleri göz ardı etmeye alışır. Özellikle suç gibi toplumsal bir meselenin kişisel hayat hikâyesiyle bir araya getirilmesi, mevcut düzenin en iyisi olduğuna dair gerçekliği izleyiciye aktarır (Ryan ve Kellner, 2010, s. 18). Düşünülmesi gereken ise, sunulanın saf gerçeklikten ibaret olmadığıdır. Pezzella'nın belirttiği gibi, filmler saf bir gerçeklik sunamazlar. Bunun nedeni, filmsel gerçekliğe herkesin aynı açıdan bakmasının mümkün olmamasıyla ilişkilidir (2006, s. 52). Dolayısıyla belirli bir gerçeklik üretilirken kullanılan sinema dinamiklerinin farklılığ 1 , gerçeklik etkisinin yoğunluğunu değiştirecektir. Böylece her suç filminin dinamiklerinin farklı olacağını göz önünde bulundurmak gerekir. Aynı suç teması ve aynı tip suçlulardan yararlanan farklı iki filmin sunduğu ideolojiler bile değişebilirken, popüler bir suç filmiyle, çağdaş anlatı temelli bir suç filminin sinemanın dinamikleri aracılığıyla ortaya koyduğu ideolojilerin belirgin şekilde farklılaşacağı söylenebilir. Çalışma amacına uygunluğu açısından ise bu kısımdan sonra popüler suç filmlerinin ideolojilerine yer vermek anlamlı gözükmektedir.

\section{Popüler Suç Filmlerinin İdeolojisi}

Benjamin, teknik yeniden üretimde sanat eserlerinin aurasını yitirdiğini savunurken; Baudrillard'ın belirttiği gibi, ürünlerin statülerinin de değiştiğine vurgu yapmaktaydı. Böyle bir çıkış noktasından hareketle, sinemanın bünyesinde yeniden doğan ve özünden tamamen farklı şekilde ortaya çıkabilen suç üzerine düşünülebilir (2011a, s. 97). Sinemada suç yeniden üretilir ve sunulur; ancak bu durum Benjamin'in bahsettiği aura yitiminden fazlasıdır. Öyle ki, özünden yepyeni ve farklı bir üründür. Sinema aracılığıyla suç aurasını kaybetmekten öte, kendine yeni bir aura oluşturabilir. Dahası, Pezzella'nın söylediği şekliyle, popüler sinema en çirkin ve en kötü kabul edilen olguları bile ideolojik bir hamleyle normalleştirebilir (2006, s. 23). Hatta suçun sistem tarafindan gerekli görülen bir eylem olduğu söylenebilir. Örneğin, Foucault'nun değindiği gibi, suç yoksa polis de yoktur. Polisin varlığını toplumun kabul etmesini sağlayacak tek neden, suçun toplumda olmasıdır. Suç var oldukça polis aklanabilecektir. Polisin aklanmasında ise suç ișleme eğilimindeki kișilerin ne kadar çok ve tehlikeli olduğunu anlatan makale, gazete ve filmler yoğun şekilde kullanılır (2012, s. 31). Böyle bir aklanmanın film ayağında Hollywood'un yeri önemlidir. Roloff ve Seeßlen'in düşüncelerinde olduğu gibi, barbarlık-uygarlık, mantık-eylem, yerellik-sömürge gibi kavramların arasında duran ve neredeyse hep beyaz olan Hollywood filmlerinin polisleri, Amerikan ideolojisinin yürütücüleridir (1997, ss. 245; 345; 347). Roloff ve Seeßlen de Foucault ile aynı yargıya ulaşmaktadır: Polislere ihtiyaç vardır. Hollywood ise ideolojik bir tavırla polisi haklı çıkarmanın ve meşrulaştırmanın yollarını bulmuştur; fakat bu tür filmler sadece polisleri haklı çıkarmaz. Dolayısıyla suç ve suçlunun merkeze alındığı popüler suç filmlerinde sunulan ideolojilere daha ayrıntılı değinilmelidir. $\mathrm{Bu}$ ise popüler suç filmlerinin çıkış noktası olan Hollywood suç filmlerinin tarihsel süreçteki gelişimini takip etmekle mümkün hâle gelir.

İlk olarak Sherlock Holmes Baffled (Arthur Marvin, 1900) filmiyle suç ve suçlu görünümüne eşlik etmeye başlayan seyirci, The Great Train Robbery (Büyük Tren Soygunu, Edwin S. Porter, 
1903) filminde suçun gerçek bir anlam bütünlüğü içinde ele alınışına bakma firsatı yakalamıştır. Execution of Czolgosz With Panorama of Auburn Prison'da (Edwin S. Porter, 1901) ise seyirci, Başkan William McKinley'in suikastçısı Leon Czolgsz'un elektrikli sandalyede idam anına tanık olmuştur (Pearson, 2008, s. 36). Bu ilk deneyimler bile suç üzerinden bazı ideolojilerin sunulacağının habercisiydi; fakat bu tür filmlerdeki asıl ideolojik yapılanmanın 1909 yılında American National Board of Censorship (NBC) kurulunca gerçekleştiği söylenebilir. NBC'in standartlarına göre, filmlerde suçun sonuçları uzun vadede suçlular için yıkıcı olacak şekilde gösterilmeliydi. Filmlerin vermesi gereken izlenim, suçtan elde edilen kazançların geçiciliği ve değersizliği olmalıydı. Suç işleyen kişi elbet büyük bir felaketle karşılaşmalı ve bu felaketin suçtan kaynaklandığına dair anlam filme hâkim olmalıydı (Maltby, 2008, s. 277). Dolayısıyla suç filmlerinde 'suç ve ceza ilişkisinin vazgeçilmezliğinin geleneğe dönüştürülmesi, NBC' in kurulduğu 1909 y1lıyla bağlantılanabilir. Bu tarihten itibaren suç büyüdükçe cezasının da büyüyeceği, bu cezanın ise polis ve adalet teşkilatı tarafindan uygulanacağına dair söylem ve imgeler suç filmlerinde egemen olmaya başladı. 1930'lardaki sansür yasaları da "suç açıkça gösterilemez ve özendirici olamaz", "uyuşturucu madde ticareti asla gösterilemez" gibi ifadelerle böylesi bir filmsel yapıyı destekledi (Dixon, 2013, ss. 79,80). Böylece suç istenmeyen, engellenmesi gereken ve tüm topluma zararlı bir eylem olarak uzun süre perdede yerini aldı. Böylece İkinci Dünya Savaşı'nın başlangıcına kadar Federal Soruşturma Bürosu (Federal Bureau of Investigation-FBI) ajanları, hâkimler, savcılar gibi kanun koruyucular suç filmlerinde kahramanlaştırıldı (Kakınç, 1993, s. 44). Sonuçta ise insanlara 'güçlü devlet' ideolojisi yerleştirildi.

İkinci Dünya Savaşı ve sonrası yıllara gelindiğinde suç filmlerinin yapısı değişti. Gerçek anlamda bir suç film türü olan ve çürümüş dünyanın izlerini taşıyan 'kara film'ler üretildi (Roloff ve Seeßlen, 1997, s. 242). Bu filmler savaş sonrası insanlarda oluşan suç, yozlaşma, karanlık ve tehlikeli sokaklar algısını betimlemekteydi (Schrader, 1972, ss. 8,9). Öte yandan, kara filmlerde aile ya temelde olmayacak ya da yozlaşmış olacaktı (Klinger, 2010, s. 118). Artık suç, kanun ve kanun görevlilerinin bakış açısından değil, suçluların gözünden sunabilmekteydi (Borde ve Chaumeton, 2006, s. 20). Tüm bunlara rağmen, suçlular cezalandırılmaya ve ölüme mahkûm şekilde gösterilmeye devam etti. $\mathrm{Bu}$ ideolojik tavır, ilerleyen yıllarda da sürdü. Eski şiddet veya ölüm görüntülerinin gülünç bir hâl alması, insanlara kanıksatılmaya çalışılan ideolojiyi de sarsacağından, şiddet ve ölümün gerçekçiliği daha da önem kazanmıştı. İşlenen cinayetler daha vahşileşmiş, sahneler daha islak, renkli, tiksindirici hâle gelmişti. Abisel'in vurguladığı gibi, artık suç ve ceza izleyicilere şiddetin hissettirilmesiyle değil, bizzat teknik olanaklarla oluşturulan gerçekçi vahşet görüntüleri eşliğinde sunuluyordu (1995, s. 157).

Suç filmleri 1960'lardaki toplumsal hareketler ve Liberalizm'in yükselişe geçmesiyle, insanların para karşısındaki acizliğine dair ideolojiler barındırmaya başladı (Ryan ve Kellner, 2010, s. 137). 1970'lere gelindiğinde, toplumsal hareketlerin merkezinde olan savaş karşıtları, üniversite öğrencileri ve insan hakları savunucularının hepsi, suç filmlerinin ideolojisinden nasibini aldı. Polislerin müdahalesi çok sert olsa bile, muhalifler asıl suçlular ve caniler olarak sunuldu. Seyircinin suç filmlerinden edineceği ideoloji, polisin haklılığıydı. Madigan (Dedektif Madigan, Don Siegel, 1968) ve Coogan's Bluff (Ölüm Oyunu, Don Siegel, 1968) filmlerinde bunu görmek mümkündür (Roloff ve Seeßlen, 1997, ss. 309-312). Bu tür filmlerde polislerin bazı eylemlerine göz yumulabilmesi gerektiği yoğun şekilde destekleniyordu. Böylece suçun ölçüsü ne olursa olsun, karşıllı̆ında uygulanan şiddetin yoğunluğu haklı görülecekti.

1980'lerde suçun görünümleri gibi, barındırdığ 1 ideolojiler de değişim gösterdi. Filmlerin 'aşk' ve 'aksiyon' üzerinden pazarlanması, artık yeterli değildi. Hollywood bu kodlar yerine 'seks' ve 'şiddet' temalarına yönelmenin faydalı olacağına inandı (Monaco, 2010, s. 263). Hollywood'un özellikle 1980'lerden sonra seks ve şiddete çok daha fazla yer vermesi, Amerika'da giderek sertleşen bireysellik ve güç olgularıyla ilişkili gibi 
durmaktadır. İnsanların kapitalizmin merkezinde hayatta kalabilmeleri için daha acıması olmaları gerektiğine dair yaygın ideoloji, aşk ve aksiyon yerine daha sert olgulara ihtiyaç olduğunu düşündürmüştür. Aynı düzlemde Hollywood bu iki kavramın vahşi dönüşümleri olarak, seks ve şiddeti kullanmayı yararlı görüyordu; çünkü 1980 sonrası toplumsal gerçekliğe bu iki kavram çok daha uygundu. Filmlerde seks ve şiddetin yoğunlaştırılması, gerilimin de giderek artmasıyla sonuçlandı. Gerilim ise 'belirsizliğin estetik etkisi' aracıllğıyla, seyirciye daha uzun süreli bir haz vaat edebiliyordu. Böylece 1980 sonrasının seyircisi suç filmlerinde sunulan gerçekliğe daha fazla odaklanarak, sunulan ideolojilerden ayn1 doğrultuda etkilenmeye hazır hâle getirildi. Yine aynı yıllarda filmler özellikle beyaz erkek bilinciyle şekillendirilmeye devam etti. Bu erkekler suçları çözen ve casusları yakalayanlardı. Beyaz erkeklerin mental yönden güçlü gösterilişleri, bedenlerinin sunumuna da yansımaktaydı. Sonuç ise 'güçlü beyaz erkek' ideolojisinin beden aracılığıyla da yoğun şekilde suç filmlerinde aktarılmasıydı. Grant'ın vurguladığı gibi, bu yıllarda Arnold Schwarzenegger, Sylvester Stallone, Jean-Claude Van Damme, Steven Seagal, Chuck Norris ve Bruce Willis gibi yıldızlar, hareketlerinden çok vücutlarıyla seyirciyi etkiliyordu (2011, ss. 175,176). Dolayısıyla bu tür beyaz erkekleri 1980 sonrası suç filmlerinde de s1klıkla görmek mümkün oldu.

1990'larda Hollywood suç filmlerinin yapısı Amerika'daki sosyo-kültürel olaylar ve teknolojik gelişmelere bağlı olarak değişmeye devam etti. Terörizmin yükselişi, çevre krizi, rrkçılık ve din üzerine söylemler, cinselliğin yoğunlaşması vb. durumlar filmlere yoğun şekilde sirayet etmeye başladı. Benzer şekilde, toplumda bu yıllardan itibaren giderek artan suç oranı, Hollywood'un suç temalı filmleri de yoğunlaştırmasını kaçınılmaz hâle getirdi. Hatta suç, Hollywood'un ideoloji üretimi ve yayllımında etkili bir hammaddeye dönüştü. Böylece bireycilik, kapitalizm, ataerkil toplum anlayışı, toplumsal uyum, din, rrkçılık, polisin meşruluğu gibi ideolojiler suç filmlerinde çok daha sık kullanılmaya başladı. Artık suçun temsili, suçun gerçekliğinden ayrı bir öze sahipti.
Popüler filmlerde suç, gerçekliğinden çok farklı bir gösteri ve estetik içinde sunuluyordu. Son yıllarda ortaya çıkan Drive (Sürücü, Nicolas Winding Refn, 2011), Looper (Tetikçiler, Rian Johnson, 2012), American Hustle (Düzenbaz, David O. Russell, 2013), John Wick (Chad Stahelski \& David Leitch, 2014), The Hateful Eight (Quentin Tarantino, 2015), Nocturnal Animals (Gece Hayvanları, Tom Ford, 2016), Baby Driver (Tam Gaz, Edgar Wright, 2017) ve Death Wish (Öldürme Arzusu, Eli Roth, 2018) gibi filmler bu durum için iyi örneklerdir. $\mathrm{Bu}$ tür filmlerde gösteri malzemesi olarak kullanılan suç ve suçlu üzerinden din, aile, devlet, toplum, cinsiyet, $1 \mathrm{rk} \mathrm{vb}$. hakkındaki gerçekliklerin yeniden üretildiğini görmek mümkündür.

\subsection{Popüler bir suç filmi olarak Kabadayı'nın ideolojisi}

Bir önceki kısımda görüldüğü üzere, Amerika'nın tarihsel süreçte yaşadığ teknolojik ya da siyasi değişimler, popüler suç filmlerine de yansımış ve bu tür filmler aracılığıyla sunulan ideolojilerin farklılaşmasına neden olmuștur. $\mathrm{Bu}$ durum, özellikle popüler suç filmlerinin çoğalmaya başladığı 1990'larla, Kabadayı'nın üretildiği 2007 yılı arasındaki tarihsel süreci Türk sinemasındaki gelişmeleri de göz önünde bulundurarak değerlendirmek gerektiğini hatırlatmaktadır.

Türkiye'de 1990'larda liberalizmin yükselişe geçmesiyle birlikte kolay para kazanma, işsizlik, yoksulluk ve hızlı kentleşme gibi konular da gündeme gelmiştir. $\mathrm{Bu}$ gündem, aynı zamanda Türk toplumunda mafyalaşmaya müsait bir yapı oluşturmuştur. Buna bağlı şekilde, suç ve şiddet olaylarının artışı kaçınılmaz olmuş, çeteler kendi suç imparatorlukları çerçevesinde kara para aklama, cinayet, yaralama, dolandırıcılık vb. suçları işleyecekleri geniş bir coğrafya bulmuştur. Böyle bir toplumsal değişim ve mafyalaşmanın ilk olarak geniş ve etkili şekilde Eşkıya (Yavuz Turgul, 1996) ile görünüm kazandığ 1 söylenebilir. 1980'lerde iyiden iyiye sinemadan uzaklaşan seyirciyi geri kazanan Eşkıya'nın günümüz Türk sinemasına büyük etkisi oldu. 1990'larda hiçbir filmin başaramadığ 1 şekilde 2,5 milyon seyirciye ulaşan filmin konu açısından dikkate değer yanı, 
suç ve suçludan hareket ederek, kendinden sonraki filmlere yol haritası sunmasıydı. Suç ve suçluyu iyi bir popüler malzeme olarak kullanan filmin bu denli övgüyle karşılanması, 1990 sonrası Türk seyircisinin ne tür bir beklenti içinde olduğunun da kanıtını oluşturuyordu: Aksiyon, suç ve dram. Bu üç beklentiye cevap niteliğinde olan Eşklya, aynı zamanda Şener Şen tarafından hayat verilen Baran gibi bir anti-kahramana hayranlık duyulmasının yolunu açmayı başardı. Dolayısıyla Baran'a duyulan hayranlığın, suç filmlerinde daha sonra giderek yoğunlaşarak kullanılacak olan antikahramanların önünü açtığı düşünülebilir. Böylece Eşkıya sonrası filmlerde aile, din, devlet, toplum, cinsiyet, 1rk vb. ideolojilerin anti-kahramanların görünüm ve eylemlerine yüklenmesinin de yolu açılmış oldu.

2000'lerin başında (Kasım 2000, Şubat 2001) Türkiye'nin yaşadığı ekonomik krizler sonrası ortaya çıkan toplumsal sorunlar arasında suç ve şiddetin üst basamaklarda yer aldığ 1 söylenebilir. $\mathrm{Bu}$ duruma bağlı şekilde, Yeşilçam'ın standart kadın-erkek ilişkisine dayalı olay örgüsünden kopan popüler Türk sineması, erkeğin/erkekliğin çok daha fazla yüceltildiği ve milliyetçiliğin kol gezdiği bir yapıya bürünmüştür (Büyükdüvenci ve Öztürk, 2007, s. 49). Böyle bir yapının erkek antikahramanların çoğalmasını kaçınılmaz hâle getirdiği söylenebilir ve nitekim öyle de olmuştur. 2000 y1lından itibaren erkek anti-kahramanların yer aldığ dizi ve filmler yoğunlaşmaya başlamıştır. $\mathrm{Bu}$ dönemin erkek anti-kahramanlarını Yücel şu şekilde sıralamaktadır (2014, ss. 5,6): Yusuf Miroğlu (Kenan İmirzalıoğlu), Polat Alemdar (Necati Şaşmaz), Boran Genco (Mehmet Akif Alakurt), Yandım Ali (Kenan İmirzalığlu), Ali Osman (Şener Şen), Yiğit Sancaktar (Erkan Petekkaya), İskender Büyük (Musa Uzunlar), Maraz Ali (Mehmet Akif Alakurt), Murat Şahin (Haluk Piyes) ve Ezel Bayraktar (Kenan İmirzalıoğlu). Tüm bu anti-kahramanlar Deli Yürek (1999), Kurtlar Vadisi (2003), Sila (2006), Sessiz Fırtına (2007), Adanalı (2008), Aynadaki Düşman (2009), Ezel (2009) gibi dizilerde ya da Deli Yürek: Bumerang Cehennemi (Osman Sinav, 2001), Kurtlar Vadisi: Irak (Serdar Akar, 2006), Son Osmanlı: Yandım Ali (Mustafa Şevki Doğan,
2007), Kabadayl (Ömer Varg1, 2007), Kurtlar Vadisi: Gladio (Sadullah Şentürk, 2009), Kurtlar Vadisi: Filistin (Zübeyr Şaşmaz, 2011), Kurtlar Vadisi: Vatan (Serdar Akar, 2017) gibi filmlerde boy göstermiştir. Günümüzde tüm bu antikahramanları yoğun şekilde dizi ve filmlerde görmek mümkündür. Öte yandan, 2000'lerden itibaren topluma lay1k görülen tüm bu antikahramanlar, aslında saldırgan katiller, mafya babaları, tecavüzcüler ve hayatı tüketen bireylerdir (Süalp, 2009, s. 140). Her şeyden önemlisi ise hepsi birer suçludur. Bu minvalde, suçlu karakterin hangi kategoriye yerleştirileceği önemlidir. Örneğin, Türk toplumunun sempati duyacağ suçlunun meşru görülemeyecek eylemlerinden belki en önemlisi tecavüzdür. Suçluya böyle bir eylemsel özelliğin aşılanması, suçlunun anti-kahraman olarak algılanmasına engel olacağ gibi, seyircinin filmden kopmasina da neden olabilir. Daha da önemlisi, bu durum suçlu karakter aracılığıyla aktarilacak ideolojilerin reddine neden olacaktır. Popüler suç filmleri bunun bilinciyle suçlu karakterler tasarlar ve onları seyircinin gözünde kahramanlaştırır. Dolayısıyla popüler Türk suç filmlerinin anti-kahramanlarında böylesi bir eyleme rastlamak çok mümkün değildir; çünkü anti-kahraman özünde iyi bir insan olduğu bilincini seyirciye yansitacak eylemsellikle donatılmalıdır. Zaten böyle bir özelliğe sahip değilse, antikahraman değil, sadece bir suçlu olarak anılacaktır. Ayrıca anti-kahramanın toplumsal değerlerden saptı̆̆ da görülebilir; fakat filmsel anlatı bu tarz eylemleri her ne kadar meşrulaştırıyor gibi görünse de, temelde onları cezaya mahkûm etmeyi ihmal etmez. Bu tarz bir sinemasal hamlenin, ideolojik anlamda farklılığı yok etmeye değil, evcilleştirmeye yönelik olduğu söylenmelidir. Oskay'ın da belirttiği gibi, evcilleştirme egemen ideolojinin popüler kültür uygulamalarından biridir (1980, s. 248). Dolayısıyla popüler suç filmlerinde de evcilleştirmenin ideolojik bir hamle olduğu düşünülmelidir. Özellikle din ve devlet karşısında insanların evcilleştirilmesi, suçlu karakterler aracılı̆̆ıyla yoğun şekilde suç filmlerine sirayet eder. 


\subsubsection{Evren ve örneklem.}

Popüler bir filmin başarısı, genellikle seyirci sayısı ve gişe hasılatı üzerinden değerlendirilir. Öte yandan, geniş seyirci kitlesine ulaşmayı başaran popüler filmlerin, her zaman kendi yararına hizmet etmediğini söylemek gerekir. Eşkıya bundan fazlasını başaran nadir filmlerden biridir. 2,5 milyon seyirciye ulaşan film, sadece yüksek bir gişe başarısı sağlamamış, Türk sineması için de bir kırılma noktası oluşturmayı başarmıştır. Türk Sinema Araştırmaları'nın veri tabanında ${ }^{i}$ da görüldüğü üzere, film özellikle 1980'lerde sinema salonlarından kopan izleyiciyi yeniden salonlara bağlamayı başarmıştır. Eşkıya'nın başarısına heveslenen pek çok yönetmen, suç ve suçlunun temele alındiğı popüler filmler çekmiş ve 2000'lerden itibaren suç ve suçlu temalı filmlerde büyük yoğunluk yaşanmıştır. Bu filmlerde Türk seyircisine bir taraftan komedi, bir taraftan suç ve dramın yoğun şekilde pompalandığ gözlemlenmektedir ve bugün çekilen filmlerde de durum çok farklı değildir. Seyirci ise bu tarz filmlere olumlu karşllık vermiştir. Bunun en iyi kanıt1, gişe hasılatı yapan filmlerin hangi temalardan hareket ettiğine bakıldığında anlaşılmaktadır. Boxoffice Türkiye verilerine ${ }^{\mathrm{ii}}$ göre, en çok gişe yapan filmler arasında suç, dram ve komedinin yoğunlukta olduğu söylenebilir. Konuya uygunluğu açısından hem bu listede yer alan, hem de suç ve suçlunun temele alındığ 2000 sonras1 popüler Türk filmleri şu şekilde sıralanabilir: Organize İşler (Yılmaz Erdoğan, 2005, Komedi), Kurtlar Vadisi: Irak (Serdar Akar, 2006, Aksiyon/Politik), Kabadayı (Ömer Varg1, 2007, Suç), Maskeli Beşler: Irak (Murat Aslan, 2007, Komedi/Aksiyon/Savaş), Muro: Nalet Olsun İçimdeki İnsan Sevgisine (Zübeyr Şaşmaz, 2008, Komedi), Yahşi Batı (Ömer Faruk Sorak, 2010, Komedi/Fantastik/Western), Av Mevsimi (Yavuz Turgul, 2010, Macera/Dram), New York'ta Beş Minare (Mahsun Kırmızı̈ül, 2010, Macera/Dram), Kurtlar Vadisi: Filistin (Zübeyr Şaşmaz, 2011, Macera/Aksiyon), Sen Kimsin? (Ozan Açıktan, 2012, Komedi), Çakallarla Dans 3: Sifir Sikıntı (Murat Şeker, 2014, Komedi), Ali Baba ve 7 Cüceler (Cem Y1lmaz, 2015, Komedi), Çakallarla Dans 4 (Murat Şeker, 2016, Komedi), Kolpaçino 3.
Devre (Şafak Sezer, 2016, Komedi), Çakallarla Dans 5 (Murat Şeker, 2018, Komedi), Organize İsler: Sazan Sarmalı (Yılmaz Erdoğan, 2019, Komedi/Aksiyon).

Görüldüğü üzere, yukarıda zikredilen filmlerin çoğunda suç ve suçlu, komedi temasıyla bir arada seyirciye sunulmaktadır. Yani tüm bu filmler bir şekilde suç eylemlerine yer vermesinden dolayı değerlendirmeye uygun olabilecek kadar geniş bir örneklem alanı sunar. $\mathrm{Bu}$ filmler arasından Kabadayı (Ömer Varg1, 2007), örneklem olarak belirlenmiştir. Kabadayı, yukarıda bahsi geçenler arasında 'suç filmi' türüne dâhil edilen tek filmdir; fakat Av Mevsimi gibi bir filmin de benzer yapıda olmasına karşın, suç türüne dâhil olmadığ 1 gözlemlenmektedir. $\mathrm{Bu}$ açıdan, Kabadayı'nın sadece bir suç filmi olduğu için örneklem olarak seçildiğini söylemek doğru olmaz. Filmin örneklem olarak belirlenmesindeki asıl neden, 2000'lerdeki pek çok anti-kahramana hayat veren Kenan İmirzalığlu ile 1996'ya kadar hiçbir filmin ulaşamadığı seyirci sayısına ulaşmayı başaran Eşkya'nın (Yavuz Turgul, 1996) anti-kahramanı Şener Şen'i karşı karşıya getirmesiyle ilişkilidir. $\mathrm{Bu}$ iki suçlunun mücadelesi, günümüz filmlerinde de sıklıkla rastlanılan suç ve suçlu üzerinden aktarılan ideolojilere bakabilmek adına yoğun bir malzeme birakmaktadır.

\subsubsection{Yöntem.}

Araştırma örneklemini oluşturan Kabadayı filmi, ideolojik yöntem kullanılarak çözümlenmiştir. Bu çözümleme yapılırken filmin biçim ve içerik öğelerinin her biri değerlendirilerek, hangilerinin suç ve suçlu üzerinden ortaya koyulan baskın ideolojiler barındırdığı tespit edilmeye çalışılmıştır.

Filmsel bir anlatı zaman ve mekânı ne şekilde kullanırsa kullansın bir şekilde ideolojiktir (Comolli ve Narboni, 2010, s. 99). Filmler ideolojik yapılar olarak düşünüldüğünde, filmsel anlatının 'nasıl' kısmıyla ilgili olduğu anlaşılır. Yani nasıl bir ideoloji sunulduğuna ek olarak, ideolojinin nasıl sunulduğu da önemlidir. Dolayısıyla filmin anlatısı sadece öykü (içerik) üzerinden değil, öykünün nasıl işlendiği (biçim) üzerinden de değerlendirilmelidir. Ryan ve 
Kellner, bu yönden anlatının kapanma tarzı, devamlılık kurgusu, kamera işleyişi (karakter özdeşleştirme, dikizcilik), neden-sonuç ilişkisi, dramatik güdüleme, çerçeveleme, gerçekçilik hissi gibi kullanımlarla egemen değerleri aktardığına vurgu yapar (2010, s. 17). Yine Corrigan, ideolojik çözümlemede biçim ve içerikle birlikte filmin karakterlerine de bakmak gerektiğine değinir. Ona göre, filmin ideolojisi karakterlerin birbirleriyle kurdukları ilişkilerin nasıl olduğu ve filmin bu konuda ne önerdiği (bireysellik, aile, toplumsal değerlerin sunumu, erkek ve kadın konumlandırması, farklı $1 \mathrm{rk}$, dil, din ya da mezhepten olanların nasıl gösterildiği) üzerinden değerlendirilmelidir (2011, s. 124).

İdeolojiler, toplumsal süreçler olarak görülmelidir (Therborn, 1989, s. 7). Benzer durum sinema için de geçerli olduğundan, belirli bir dönemin filmlerini, o dönemin ideolojisiyle bir görmek anlamlıdır. Yani ideolojik çözümlemede filmin üretildiği tarihsel dönem göz önüne alınmalıdır. İdeolojik mesajları sadece dil kısmında arayan yapısalc1 bir perspektiften hareket etmek, tarihselliğin göz ardı edilmesinden dolayı eksik olacaktır (McLellan, 2012, s. 74; 78). Dolayısıyla ideolojik çözümleme de tarihsel eleştiriden de faydalanılmalıdır.

İdeolojik bir film çözümlemesi temelde Marksist kuramdan hareket eder. $\mathrm{Bu}$ açıdan ideolojik yaklaşım, özellikle ticari filmlerin üretim, dağıtım ve gösterim pratikleri üzerine yorumlarda bulunabilir. Filmler kültürel bir pratik alanı olarak estetik, sosyoekonomik, tarihsel anlamlandırma ve güdümleme aracı şeklinde değerlendirilir. İdeolojik yaklaşımda filmlerle ilgili olarak genelde şu sorulara cevap aranır (Özden, 2004, s. 167):

- Filmler, seyirciyi nasıl bir ideolojik konumlandırma içine yerleştirmektedir?

- Filmler, içinde bulundukları tarihsel dönem ve sınıfsal ilişkiler bağlamında düşünceler, değerler ya da toplumsal konumları nasıl yeniden üretmektedir?

- Filmsel metinlerin altında yatan ideolojik mesajlar nasıl ortaya çıkarılabilir?

- Filmler, egemen ideolojinin yeniden üretiminde nasıl bir işlev görmektedir?
- Filmler, oluşturdukları gerçekliği seyirciye nas1l kabul ettirir?

Tüm bu açıklamalar dâhilinde örneklem olarak belirlenen Kabadayı filmi ele alındığında, filmin ideolojisinin ortaya çıkarılabilmesi için öncelikle öykünün yürütücüsü konumundaki karakterlerin fiziksel, psikolojik, kültürel ve ilişkisel yönlerden nasıl yapılandırıldığına bakılmıştır. Daha sonra filmin biçimsel yönünü oluşturan kurgu, kamera, 1şık, renk, ses, müzik, zaman ve mekânın kullanımında baskın ideolojik tavrın ne olduğuna odaklanılmıştır. Ayrıca tüm bu öykü ve olay örgüsü öğelerinin, filmin içinden çıktığı tarihsel dönemle bağlantısı ekseninde değerlendirilmesi gerekmiştir. Tüm bunlar sonucunda çalışmada şu sorulara yanıt aranmaya çalışılmıştır:

- Film, seyirciyi nasil bir ideolojik konumlandırma içine yerleştirmektedir?

- Film, içinde bulunduğu tarihsel döneme bağlı olarak, karakterler arası ilişkileri toplumsal değerler bağlamında nasıl yeniden üretmektedir?

- Film, suçu egemen değerler ve kurumlar bağlamında yeniden üretmekte midir?

- Filmin suç üzerine oluşturduğu gerçeklik nedir? $\mathrm{Bu}$ ideolojik gerçekliğin oluşturulmasında filmin kurgu, kamera, ş̧ık, renk, ses, müzik, zaman ve mekân gibi anlatı kodlarının nasıl bir etkisi bulunmaktadır?

\subsubsection{Bulgular ve yorum.}

Kabadayı filminde suç, suçlu, ceza kapsamında özellikle aile, din, devlet ve cinsellik üzerine topluma hâkim düşüncenin yeniden üretildiğine dair çeşitli ideolojilere rastlanmıştır. Bu baskın ideolojiler, filmsel anlatının öykü (içerik) ve olay örgüsü (biçim) kodlarıyla bunların altkodlarında gözlemlenmektedir.

\subsubsection{1. Öykü ve ideolojik tavir.}

Eski kabadayı ve suçlu olan Ali Osman, etik bulmadığ1 için kabadayılık yapmaya tövbelidir. Aralarında arkadaşlarının da bulunduğu tüm eski 'camia' ona saygı duyar. Ali Osman, artık ezilenlerin yanında olmayı, fakirlere yardım etmeyi ve mahallenin 'babalığını' yapmayı kendine görev 
edinmiştir. Bir gün ölmek üzere olan eski sevgilisi Afet'ten, Murat adında bir oğlu olduğunu öğrenir. Murat'ın, Karaca ile mutlu bir ilişkisi vardır; fakat Karaca'nın peşini bırakmayan eski sevgilisi Devran her şeyi değiştirir. Devran, istihbarata muhbirlik eden bir suçludur ve istediği gibi davranabilmektedir. Karaca'ya kavuşmak için Murat'a zarar vermek ister. Murat'in oğlu olduğunu öğrenen Ali Osman ise tövbesini bozar ve Devran'la ölümüne bir mücadeleye girişir. Bu mücadelenin sonunda Murat ve Karaca hayatta kalmayı başarırken, Devran ve Ali Osman ölümden kurtulamaz. Filmsel öykü bu şekilde temellenirken, hem öykü hem de öykünün yürütücüsü konumundaki karakterler aracılığıyla suç, suçlu, ceza, aile, din ve devlet üzerine bazı gerçekliklerin yeniden üretildiği görülür. Dolayısıyla öykünün kendi gibi, öykü kişilerinin eylem ve söylemlerine bakmak gerekmektedir.

Filmin öyküsünde Ali Osman ve arkadaşları eski kabadayılar, bir nevi 'iyi' suçlular olarak sunulur. Şartlar öyle gerektirdiği için zamanında suç işlemişler; fakat bir daha işlememeye tövbe etmişlerdir. Onlar kendilerini 'mafya' değil, 'kabadayı' olarak nitelendirir ve suçun 'kötü' bir eylem olduğunu savunurlar. Henüz filmin başlarında suça yönelik böyle bir söyleme rastlamak mümkündür. Ali Osman gençken Mahmut komiser tarafindan çağrılmış ve uyarılmıştır. Haco'nun anlatmaya başladığ hikâyeyi bitirmek için Ali Osman devam eder: "Gittim, aferin yürekli delikanlıymışsın dedi. Sonra da şöyle bitirdi: Benden sana bir baba nasihatı delikanlı, bu bitirim ayaklarını bırak. Ben böyle çok ayak kırdım. Senin gibilerin sonu ya mahpus damı ya mezarlıktır. Yol yakınken dön, yazık olmasın sana." Beyto da bu olumsuzlamayı şu söylemiyle destekler: "Hakikaten onca arkadaşımızın hangisi yatağında eceliyle öldü ki; ya biçakla ya kurşunla. Biz iyi geldik bu günlere.” Eski kabadayıların bu günah çıkarmaları Ali Osman'da tamamen vücut bulmuş şekilde, tövbesini oğlu Murat için bozduğu zamana kadar sürdürülür.

Ali Osman, işlettiği halı sahada her hafta fakirlere yemek veren, mahalleli arasındaki anlaşmazlıklarda söylediği kanun yerine geçen, iyi birisi olarak resmedilir. Yardımcıları Cemil ve Atiye, Ali Osman'a tüm bunların gereksiz olduğunu söylerlerken, Ali Osman sinirlenir ve onlara itiraz eder. Tüm bunlar, bir kabadayı olarak Ali Osman'ı 'suçlu' damgasından uzaklaştırır. Zaten filmdeki genel söylemde, 'kabadayı' ve 'mafya' ayrımına vurgu yapılmaktadır. Suçu işleyen ve eylemleri meşru görülemeyecek taraf, mafyadır. Kabadayı ise fukaranın yanında olan, cinayet işlediyse de haklı bir sebebi bulunan, mahallenin saygı duyduğu kültürel bir semboldür. Böylesi bir tavırla, filmde mafyaya bulaşan taraflar olarak Patron, Devran ve Selim 'kötü suçlular' şeklinde resmedilir. Mafya ve kabadayı arasındaki temel farkl1lı̆g 1 ise Ali Osman, oğlu Murat ile girdiği tartışmada şu sözler aracılığıyla belirtir: "Ben mafya değilim, hiçbir zaman olmadım. Benim arkamda polis yoktu, milletvekilim yoktu. Ben ne uyuşturucu, ne silah, ne fahişe sattım. Ben işimi tek başıma gördüm, düşmanlarımla tek başıma hesaplaştım ve yaptığım her şeyin bedelini ödedim." Kabadayı'nın Ali Osman aracılığıyla aktardığı böyle bir söylemden ortaya çıkan sonuç ise mafya, devlet, suç bağlantısı ve buna yönelik eleştiridir.

Filmde uyuşturucu, kadın ticareti, cinayet, haraç, para aklama gibi pek çok suçun, organize suç örgütleri; yani mafyanın tekelinde olduğu aktarılır. Mafya eylemlerini gerçekleştirirken bir şekilde devletle ilişki içindedir. Başkomiserin, Devran'1 şikâyet eden Murat ve Ali Osman'a karşı söyledikleri suç, devlet, mafya ilişkisini yoğun şekilde ortaya koyar. Ali Osman, Devran'ın kim olduğunu sorduğunda başkomiser şöyle der:

Artık moda meslek, biliyorsunuz organize işler. Çete kurmak, çocuk oyuncağı, bu da en yeni elemanlarından; ama gözü kara biri. Kısa yoldan ün yapmak için her işe giriyor. Onun için uzak durmaya çalışın. Şimdi sahte şahitler çıaracaklardır, sahte tetikçiler filan. Ayrıca size de bulaşacaklardır. Yani işin doğal seyri budur. Size düşen, bu işten kazasız belasız sıyrılmaktır. Bizim de elimizin, kolumuzun bağlandığı durumlar oluyor.

Böylesi bir söylem, devletin bazı amaçları doğrultusunda kimi suçlara ve suçlulara göz 
yumduğunu vurgular. Burada eylemlerine göz yumulan suçlu ise Devran'dır. O, istihbarata bağlı Gölge amir sayesinde cezadan korunur. Filmde bunun nedeni, Devran'ın büyük bir organize suç örgütünün lideri olan Patron'un yakalanmasına destek olmasına bağlanır. Böylece devletin suçluyu koruması da belirli bir nedene bağlanarak ideolojik şekilde meşrulaştırılır ve devlet işi bittiğinde suçluyu kesinlikle cezalandıracaktır. Yani Devran ve diğer suçlular bir şekilde cezalarını çekeceklerdir. Dolayısıyla filmde Devran'ın eylemlerini meşru gösterecek hiçbir alan bırakılmaz. Sonuçta, Devran bir suçludur ve cezası muhakkak kesilecektir. Kabadayı bu cezay öykünün sonuna bırakır. Mafya olarak Devran ve adamları, kabadayı olan Ali Osman tarafindan öldürülür. Benzer şekilde, her ne kadar Ali Osman 'iyi' kodunu bünyesinde barındırsa da, suç işlediği için ölümden kurtulamaz. O da Devran'ın son nefesini vermesinden kısa süre sonra gözlerini tamamen kapatır.

\subsection{Karakterler.}

Filmsel öykünün taşıyıcısı konumundaki ana karakterlerin Ali Osman, Murat, Karaca ve Devran, yardımcı karakterlerin ise Patron, Selim, Sürmeli, Haco, Afet, Cemil, Gölge ve Teoman olduğu söylenebilir. Öykü temelde bu karakterler ve birbirleriyle ilişkileri bağlamında ilerlemektedir. Öyküyü destekleyen diğer karakterler ise Beyto, Turhan, Hasan, Talat ve Atiye' dir. Karakterlerin fiziksel, psikolojik, kültürel ve ilişkisel özellikleri aracılığıyla genelde aile, din, devlet ve toplum, özeldeyse suç ve ceza üzerine bazı ideolojilerin aktarıldığı gözlemlenmiştir.

Filmin anti-kahramanı Ali Osman'ın, kendine güvenen ve rahat duruş tarzı, zekâsı, sert yüz ifadesi, kararlı kişiliği, klasik giyimi ve tok ses tonuyla fiziksel yönden 'kabadayı' imajına uygun yapılandırıldığı söylenebilir. Psikolojik açıdan, cesaret ve pişmanlık kodlarını bünyesinde barındıran Ali Osman, geçmişte işlediği cinayetler yüzünden sürekli bir suçluluk ve hayal kırıklığ yaşar. Böylece suçun kesinlikle uzak durulması gerektiğine dair gerçeklik, Ali Osman'ın pişmanlığı aracılığıyla aktarılır; fakat kabadayılığı her zaman iyilik koduyla birlikte işleyerek, eylemlerinin meşruluğuna destek sağlar.

Öyküde 'kabadayı' ve 'iyi' kodlarının yan yana gelişinde Ali Osman'ın kişilerarası özellikleri yoğun şekilde kullanılmıştır. O, herkes tarafindan sevilen, sayg1 duyulan, iyi niyetli, fukaralara yardım eden, sözü mahallede kanun yerine geçen bir insandır. Hiç yalnız bırakılmaz; tüm dostları tarafindan desteklenir. Sonradan oğlu olduğunu öğrendiği Murat ve onun sevgilisi Karaca'yı koruma isteği, tövbesini bozarak silahını eline almasını ve Devran'1 öldürmesiyle sonuçlanan eylemlerinin başlangıcını oluşturur. $\mathrm{Bu}$ yönüyle filmin cinayet gibi bir suç eylemini meşru göstermesinde, Ali Osman'ın kişilerarası özelliklerinin önemli olduğu anlaşılır. O, ailesi için şiddet uygulamaya veya suç işlemeye hazırdır ve film bu tür eylemlerin suç olarak algılanmasına firsat vermez.

Ali Osman'ın kültürel özelliklerinin, eylemlerinde etkili olduğu ve Türk toplum yapısını yansıttığ 1 vurgulanabilir. Dinine bağl1lık, ailenin önemi, hak edene karș1 şiddetin meşruluğu, günümüz Türk toplum yapısını yansıtır niteliktedir. Öyküde Türk kültüründe kabadayıllğın sembolü niteliğinde olan tesbih, silah, aile, din, adalet gibi kavram ve nesnelerin, Ali Osman aracılığıla sürekli vurgulandığ 1 gözlemlenir. Böylece Ali Osman, eylemleri asla meşru görül(e)meyecek 'mafya' karakterinden ayrilarak, Türk toplumunun yeri geldiğinde desteklediği ve sayg1 duyduğu 'kabadayı' konumuna yerleştirilir. Ali Osman'ın bu şekilde karakterize edilmesi, eylemlerinin meşruluğuna yoğun şekilde hizmet eder. $\mathrm{Bu}$ da onun eylemlerini suç değil, adalet olarak göstererek, izleyiciye Ali Osman ile özdeşlik kurmanın yolunu sunar. Dolayısıyla ideolojik açıdan özellikle din ve aile kurumlarına ait toplumsal değerlerin Ali Osman'ın kültürel özellikleri aracillğıyla yeniden üretildiğini söylemek mümkündür.

Öykünün Ali Osman'ın karşısına çıkardığı Devran genç, uzun boylu, esmer, kendine güvenen, soğuk, alayc1, zeki, kurnaz, saplantılı gibi kodlarla donatılmıştır. Devran'ın suç eylemlerinin nedeni psikolojik temelli sunulur. Onun suçlu olmasında 
çocukken uğradığı tecavüzün etkili olduğuna dair bir anlam oluşturulur. Böylece filmde erkeklik üzerine gerçeklikler yeniden üretilmiş olur. Filme bakıldığında, Devran'ı en çok kızdıran olaylar şunlardır:

- Küçük yaştayken yetimhanede görevli tarafindan defalarca tecavüze uğraması,

- Teşkilatın (derin devlet) işlerini Devran'a yaptırabilmek için, ona dansöz kıyafetleri giydirerek fotoğraflarını çekmesi ve şantajda bulunmas1,

- Eski sevgilisi Karaca'nın, erkekliğiyle alay ederek, yeni sevgilisi Murat'in yatakta çok daha iyi olduğunu söylemesi.

Tüm bunlar filmde Devran'ın suç eylemlerinin tetikleyicileri olarak gösterilir. Özellikle teşkilatın onu dansöz kıyafetiyle fotoğraflaması ve şantajla işlerini yaptırması, Devran'a göre, kendisini psikopat ve paranoyak yapan olaydır. Dolayısıyla tüm bu yaşanmışlıklara rağmen, Devran psikopat bir katil olarak sunulmuş ve öyküde onun eylemlerini meşru gösterecek çok fazla alan bırakılmamıştır.

Devran'ın kişilerarası ve kültürel özellikleri temelde toplumsal kurum ve değerlerin suç açısından önemine dair ideolojik veriler ortaya koyar. Aile bu yönden desteklenen ve önemi vurgulanan temel toplumsal kurumdur; çünkü Devran küçük yaşta annesini ve babasını kaybetmiş, yetiştirme yurdunda büyümüşsür. Şimdi ise yalnız bir adamdır. Yalnızlığı, onu bir taraftan organize suçlara bulaştırmış, bir taraftan da teşkilatın kullandığı kişi olmasına neden olmuştur. Devran, Ali Osman gibi dini kodlarla donatılmaz; çünkü dini inancına bağlı bir suçlu olarak sunulması, toplumsal değerlere uygun bir ideolojik tavır değildir. Bunun yerine, filmde ekonomik güç ve suç üzerine bir anlam oluşturulmuştur. Yeni mafyalardan olan Devran, lüks bir arabaya ve eve sahiptir. Yaşam standartları oldukça yüksektir; ancak Kabadayl'nın yaptığı ideolojik hamle, bunun asla onu cezalandırılmaktan kurtar(a)mayacağıyla ilişkilidir. Onun cezasını devlet kesmese de Allah keser ve Devran suç eylemlerinin bedelini hayatıyla öder. Bireysel tutkular ve bağımlılıklar, uyuşturucu, zevk ve para için her şeyi yapmaya hazır olan Devran, eylemleri asla meşru görül(e)meyecek mafyaya dâhil edilir. Devran'ın bu şekilde karakterize edilmesi, eylemlerinin cezalandırılması gerektiğine yoğun şekilde vurgu yapar.

Görüldüğg̈ üzere, öyküde suç ve suçlu üzerinden ortaya koyulan ideolojiler temelde Ali Osman ve Devran aracılığıyla şekillenmektedir; ancak Murat, Karaca ve Sürmeli karakterleriyle de özellikle cinsiyet ve cinsellik üzerine bazı gerçekliklerin yeniden üretildiği gözlemlenir.

Murat'n kültürel özellikler açısından Türk toplumuna dair sembolleri bünyesinde bulundurmadığı söylenebilir. Murat, rastalı saçlar, aileden uzaklaşma, özgür yaşam, isyankârlık gibi özellikleriyle, Amerikan toplumuna ait kültürel yapıya daha uygun gözükür. Babası Ali Osman'ın, küpesiyle ilgili "küpe de seviyorsun ha! ...bunları genelde şeyler takmıyor mu, O biçimler?" söylemi, ataerkil toplum anlayışını destekleyecek kadar ideolojiktir. Benzer bir ideoloji Karaca'ya da enjekte edilmiştir. Karaca, öykü boyunca kendini duygularıyla var etmeye çalışsa da, bu firsatı çok fazla yakalayamaz. Murat ile tartışma anlarında "konuşma, sev beni" diyerek, onunla sevişmeye başlamas1, Devran'ın yanına gittiğinde, Devran tarafindan sevişmeye zorlanması ve öykü boyunca genel anlamda güzelliği ve cinselliğiyle ön plana çıkarılması yönünden Karaca, iki erkek arasındaki çatışmaya kaynaklık eden 'nesne' konumundan çok uzaklaş(a)maz. Onun filmde sadece cinsel bir obje olarak kullanılması, ataerkil toplumu desteklen yoğun bir ideoloji barındırır. Aynı durum eşcinsel olan Sürmeli'ye yaşama şansı verilmemesiyle sürdürülüyor gibi görünse de, Sürmeli karakterinin kullanımı, erkeklik hakkında öyküden farklı bir anlam çıkarılmasının yolunu açar. Öyküde Sürmeli, kendisini ‘delikanlı’ olarak tanımlayan kabadayılardan çok daha üstün bir cesaretle donatılmıştır. Onun en büyük özelliği, cesaret ve sadakattir. Bu iki özelliği Devran tarafindan öldürülmesine neden olur; fakat ayn zamanda Sürmeli'yi kahramanlaştırır. Dolayısıyla öyküde Sürmeli'nin yaşamasına izin verilmese de, eşcinseller hakkındaki toplumsal kabuller yıpratılır. Eşcinsellere belki de hiç atfedil(e)meyen 'erkeklik', 'cesaret', 'sadakat' gibi kodlar, öyküde 
tersyüz edilerek kullanılır. Böylesi kodların atfedildiği kabadayılar ise benzer şekilde, cesaret ve sadakatten arındırılmış şekilde sunulur. Bu tür bir arınma özellikle Haco karakteri üzerinden yürütülür. Ali Osman'ın öykünün sonuna doğru Haco ve tüm eski kabadayı arkadaşlarına söyledikleri, kabadayıların delikanlılıktan sıyrılmasına zemin hazırlar: "Zaten biz yokmuşuz, cesaret yokmuş, yiğitlik, mertlik yalanmış. Ölümüne arkadaşlık, dostluk falan palavraymış. (...). Dördünüz, bir Sürmeli etmezsiniz.”

\subsubsection{Olay örgüsü ve ideolojik tavır.}

Filmin öykü aracılığıyla ortaya koyduğu baskın ideolojiler, olay örgüsünde de gözlemlenmiştir. Dolayısıyla Kabadayı'da şiddet ve ceza pratiklerinin nasıl sunulduğuyla birlikte, bu sunumda kullanılan teknik kodların da ideolojik açıdan etkili olduğunu düşünmek gerekir; çünkü kurgu, kamera, ses, müzik, 1şık ve renk öğelerinden oluşan teknik kodlar tıpkı bir dil gibi, ideolojik mesajları bünyelerinde taşırlar. Yine zaman ve mekânın yapısı da ideolojik olarak kullanılmış olabilir. Özetle, filmin olay örgüsünün nasıl oluşturulduğu, ideolojik eleştiri için önemli gözükmektedir.

\subsubsection{1. Şiddet ve ceza pratikleri.}

Anlatıya 'görünen şiddet' ve 'kaba şiddet' hâkimdir; ancak sözlü bir baskı ve tehdit oluşturma açısından, karakterlerin tutum ve davranışlarını etkileyecek 'psikolojik şiddet'in de bazen kullanıldığı vurgulanabilir. Tüm bu şiddet uygulayıcılarının sonu bir şekilde ölüm olmuştur. Böylece filmde suç ve şiddet eyleminde bulunan karakterlerin affedilmediği söylenebilir. Böylesi bir ideolojik tavır, suç ve şiddete karşı toplumsal gerçekliği yansıtır niteliktedir. Öte yandan, cezalandırmanın devletin kurumları tarafindan uygulandığına dair sadece söylemlere rastlanır; cezanın uygulanmasına yönelik imaj yer almaz.

Filmde Settar, Ali Osman, Ali Osman'1n babası, Devran ve Devran'ın babasının hapse girdiğine dair söylemler yer alır; fakat film ideolojik şekilde dini, devlet kurumunun önüne koyarak, asıl cezanın Allah katında kesileceğine vurgu yapar. Bu baskın ideolojik mesajı ise Ali Osman'ın şu söyleminden çıkarmak mümkündür:

Çok günah işledim Haco, çok. Ellerimdeki kanlar hâlâ kurumadı. Allah bir biçimde bunun cezasını verecekti. (...). Allah şart şurt tanımaz, adamın cezasını kesiverir. Bak karımı elimden ald1, oğlumu aldı. Kan davasina kurban gitmesinler diye bütün akrabalarımı kendimden uzak tuttum, yapayalnız kaldım. Eee şimdi! Hayatta tutkun olduğum tek insan can çekişiyor. (...). Unutkanlık beni teslim alıyor Haco. Evet, Allah yeni bir oğul bağışladı; ama aynı Allah, onu unutacaksın diyor. Yüzüne bakacaksın; ama tanıyamayacaksın diyor. Aldığım canların, akıttığım kanların hesabı böyle soruluyor benden. Bu bedel ödetilecek.

Kabadayı'da ceza uygulayıcısı olarak sunulan Devran ve Ali Osman, 'infazcı karakter' şeklinde değerlendirilebilir. Onlar, adaleti kendine göre sağlamaya çalışan ve dolayısıyla yanlış yaptığını düşündüklerini kendisi cezalandıran kişiler olarak gösterilir. Ceza, hukuk kuralları çerçevesinde ve devletin yetki verdiği kişi ya da kurumlar aracılığıla gerçekleşmediğinden, Ali Osman ve Devran'ın eylemlerini suçtan ziyade, şiddet kapsamında düşünmek mümkün hâle gelmiştir.

\subsection{Zaman ve mekân.}

Filmdeki bazı mekânlar ve bunların kullanım tarzının bazı baskın ideolojileri yansıttığı söylenebilir. Yani, Kabadayı'nın suç mekânlarına ve bu mekânlardaki eylemlerin ne zaman gerçekleştiğine bakarak, ne tür gerçekliklerin yeniden üretildiğine dair yorumda bulunmak mümkündür.

Teo Bar (Gece): Devran'1n, adamlariyla bir gece bu mekânı basmasıyla, öykünün durağanlığında bir kırılma yaratılır. O gece mekân, Devran'ın iki cinayetine şahitlik ederken, gerek karakterler, gerekse nesneler açısından cinayete uygun bir yapıya büründürülür. Mekânda yer alan nesneler zarar görürken, aynı zamanda her yer kana bulanır. Mekânın bu klostrofobik yapısına yerde hareketsiz yatan iki beden, korkuyla etrafta gezinen karakterler ve kanlar içindeki Karaca eşlik eder. Teo Bar tüm bu yapısı ve kullanımıyla, suç ve 
şiddetin her an meydana gelebileceği yer olarak 'bar' ve mafya olarak Devran'ın 'kötü' şeklinde damgalanmasına hizmet eder.

Teo Bar, her ne kadar 'suçun gece işi olduğu' gerçekliğini desteklese de, filmdeki diğer suç mekânlarında bundan farklı bir anlam çıkacağı görülür. Zira bundan sonraki suç eylemlerinin hepsi gündüz vakti işlenir. Devran bundan sonraki ilk cinayet eylemini gündüz, Ali Osman'ın evinin önünde, Sürmeli'yi öldürerek gerçekleştirir. Daha sonra yine Patron'u kendi odasında gündüz öldürür, Gölge amir ve adamlarını deniz kenarında gündüz öldürür ve son olarak kendisi de Ali Osman tarafindan gündüz vakti bir depoda öldürülür.

Depo (Gündüz): Tüm olayın çözümü için öyküde kamudan uzak olan bu mekân tercih edilmiştir. Mekânda yer alan ve bir şekilde suça bulaşmış Devran, Ali Osman, Selim ve Devran'ın iki adamı buradan çıkamaz. Selim ve diğer iki adamın öldügüne dair net bir bilgi verilmese de, kesin olarak mekânı sağlam terk edenler Murat ve Karaca'dır. Depo, bu iki karakter dışında orada bulunan herkes için büyük bir tabuta dönüşür. Depo, suçun işlenme zaman ve mekânını kültürel kodların yapısına uydurabilmiştir. Yani suç kamudan uzak, kapalı bir mekânda gerçekleşir. Dolayısıyla depo, toplumsal uzlaşımlar neticesinde 1ssızlık ve karanlığın suçun işlenmesi için uygun koşulları sağladığı ideolojisini destekler. $\mathrm{Bu}$ ideoloji, 1ssızlık ve karanlığı damgaladığı gibi, seyirciye de böylesi yerlerden kaçınılması gerektiğine dair mesajlar iletir.

\subsection{Teknik kodlar.}

Filmde kullanılan ses, müzik, kurgu, kamera, ışı ve renk gibi teknik anlatı kodlarının, suçun nasıl algılanması gerektiğine dair ideolojiler barındırdığ 1 gözlemlenmiştir.

Filmin geneline dramatik ve gerilimli müzik teması hâkimdir. Bu tema, suçun ağır sonuçlarını ortaya koymak için önemlidir; fakat suç ve suçlu hakkındaki ideolojilerin daha net şekilde kurgu aracılığıyla aktarıldığı anlaşılır. Örneğin, Ali Osman'ın kabadayılığını simgeleyen yüzük, tespih ve silah nesnelerinin ayrıntı planına yapılan kesmelerin, kabadayılık olgusunu yeniden ürettiği söylenebilir. Yine çekim süresinin suçun nasıl algılanması gerektiğine dair ideolojilerle ilişkili olduğu vurgulanmalıdır. Filmde Devran'ın, Teo Bar'a gerçekleştirdiği silahlı baskın sahnesi, 106 saniyelik tek bir çekimden oluşabilmektedir. Dolayısıyla çatışma, şiddet ve suç eylemlerinin, panik ve heyecan kodlarıyla desteklendiği böyle bir sahne, suçun doğasına yönelik gerçekliğin yeniden üretilmesine katkı sağlar. Seyirci bu tek çekimlik sahnede, suçun dramatik yapısına daha fazla tanık olma firsatı yakalar. Asıl gerilim ise, sahnenin ayrıntısına flasback ve yavaşlatılmış görüntü eşliğinde tanık olunduğunda ortaya çıkar. $\mathrm{Bu}$ sahnede seyirci, Teo Bar'da yaşananların sonuçlarına tanık olduğu uzun çekim sahnesinden daha fazla ideolojiye maruz kalır; içerideki şiddet ve cinayet anındaki gerilime daha yakından tanıklık eder. Böylece seyirci suça karşı nasıl düşünmesi gerektiğini bir kez daha anlamış olur: Suç acı verir.

Filmde seyirciye suç ve suçluya karşı takınması gerektiği tavrını ileten diğer bir teknik kod, kamera kullanımıdır. Kamera kullanımında ilk dikkat çeken, kameranın açısıdır. Bu yönüyle, filmin geneline nesnel açının hâkim olduğu söylenebilir. Seyirci film boyunca olaylara takipçi konumunda tanıklık eder. $\mathrm{Bu}$ açı, seyirciyi karakterlerden bağımsız hâle getirir. Böylece filmdeki suçlu karakterlerle daha yakın bir özdeşleşme kurulmasının önüne geçilmiş olur; olaylara bu karakterlerin gözünden bakılmaz. Kameranın bakış açısı ise, seyircinin gözetlediği karakterlerin güç ilişkilerine ve birbirlerine karşı statülerine tanıklık etmesini sağlar. Özellikle karakterler arası güç ilişkisini göstermek adına yoğun şekilde kullanılan alt açı önemlidir. Örneğin, Devran'ın gücünü simgeleyen alt açı kullanımına dair pek çok sahne gözlemlenir. Alt açıya uygun şekilde, Devran karşısındaki karakterlerden daha üst bir statüye konumlandırılır. O ayaktayken, çatışma yaşadığ 1 karakterler ya oturur ya da Devran karşısındaki karakter(ler)den daha yüksek bir yerde durur. Buna istisnai tek filmsel an, Ali Osman ile karşılaştı̆̆ 1 depo sahnesidir. Depoda ölmeden önce Devran sandalyede otururken, Ali Osman ayakta, onun başına silahını doğrultmuş şekilde sunulur. Böylece hem Ali Osman'ın üstünlüğü, hem de onun aracılığıyla kabadayılığın kültürel bir değer olarak 
toplumsal kabulüne firsat verilmiş olur. Bu kamera kullanımının ideolojik yanı ise, seyircinin mafya değil, kabadayıyla özdeşleşmesine hizmet etmesiyle ilişkilidir.

Suçun doğası üzerine baskın ideolojiler üretilmesine destek sağlayan kamera kullanımında değerlendirilmesi gereken son altkod, kamera hareketleridir. Anlatı boyunca oldukça durağan ve yavaş olan kameranın, Teo Bar'a yapılan baskın sahnesinde olabildiğince gezindiği görülür. Devran ve adamları bara silahlı baskın yaptığında, kamera onların olay yerini terk etmesini bekler, onlar gittikten sonra yavaşça içeriye girer ve gezinmeye başlar. Bu gezinme oldukça yavaştır; fakat barda yaşanan tüm şiddeti gözler önüne serer. Önce Teoman'1 kadraja alan kamera, yerdeki kanları takip ederek barın içine yönelir ve Devran'ın adamlarından birinin yerde kanlar içinde yattığını gösterir. Barda çalışanlar korku içinde sağa sola giderken, kamera gezinmeye devam eder ve Murat ile Karaca'yı kadraja alır. Karaca kanlar içindedir, Murat ise ona arkasından sarılmış yardım istemektedir. Kamerayla birlikte izleyici de tüm bir suç mekânını gezerek, suçun dehşet verici tarafina tanık olur. Bu tanıklık, izleyiciye suç ve şiddet eylemlerinin doğasına karşı bilgi verirken, aynı zamanda suçluların acıması, kötü, gaddar gibi özelliklere sahip olduklarını düşündürür.

\section{Sonuc}

Anlatının genelinde, gerek görüntüler gerekse karakterlerin söylemleri aracıllğıyla suçun olumsuz bir eylem olduğu, uzak durulması gerektiği ve işlenmesi hâlinde er ya da geç cezalandırılacağ 1 vurgulanır. Suç özellikle zamanında bu eylemi gerçekleştiren Ali Osman ve arkadaşları tarafindan olumsuzlanır. Suçun ne amaçla ve kime karşı işlendiği önemli değildir. Suç insanlara acı ve dönüşü olmayan izler bırakır. Öykü yapılandırılmasında izleyiciyi suça karşı böyle bir ideolojik konumlandırmaya sokan filmin, özellikle öykünün karakterleri aracılığıyla bu ideolojiyi sağlamlaştırarak, toplumsal değerler ya da kurumlar üzerine gerçekliği yeniden ürettiği söylenebilir. Ali Osman bu yönüyle öncül karakterlerden biridir. Onun din ve ailenin önemine yönelik yoğunlaşan söylemleri, özellikle bu iki toplumsal kurumun, ne kadar önemli ve gerekli olduğu fikrini izleyiciye aktarır. Ali Osman'ın geçmişte işlediği suçlar için pişmanlığı ise, suçun kesinlikle uzak durulması gereken bir eylem olduğu gerçeğini yansıtır. Yine öykünün yürütücüsü konumundaki karakterlerden biri olan Devran aracılığıyla ailenin önemine dair egemen fikirlere ulaşmak mümkündür. Devran'ın küçük yaşta anne ve babasını kaybetmesi, onu aile kurumundan koparmış ve organize suçlara bulaşmasında öncü olmuştur. Buna bağlı şekilde, Devran'ın dini inancı üzerine bir vurgu yapılmaz. Bunun temel nedeni, 'inanc1 kuvvetli olan birinin kötü bir suçlu olamayacağı' ideolojisiyle ilgilidir; çünkü anlatıda karaktere dini inanç yüklenecekse, onu suçlu kodundan olabildiğince uzaklaştırmak tercih edilmektedir. Ali Osman'ın iyilik, yardımseverlik, pişmanlık, dinine ve ailesine bağlılık gibi kodları bünyesinde barındırmasının sebebi de tam olarak bu ideolojik tavirla ilişkilendirilebilir.

Filmde karakterler aracıllğıyla din ve aile kurumları ya da suç ve suçlu gibi değerlerden farklı olarak, ataerkilliğin de yoğun şekilde yeniden üretildiği gözlemlenir. $\mathrm{Bu}$ ideolojinin iletiminde özellikle Sürmeli ve Karaca karakterleri etkili olmuştur. Eşcinsel olan Sürmeli toplumsal alandan dışlanır ve bu cinsel tercihinin bedelini hayatıyla öder. Her ne kadar Ali Osman gibi bir 'delikanlı' onu eski arkadaşlarına karşı 'erkeklik' koduyla yüceltse de, eşcinsellik Sürmeli'yle birlikte filmin dünyasından dışlanır. Yine Karaca anlatı boyunca duygularıyla varolmasina izin verilmeyen, güzelliğiyle dikkat çeken, erkekler arasında rekabete sebep olan kadın olarak ve ataerkil bir anlayışla, 'obje' olmaktan kurtulamaz. Dolayısıyla film karakterler arası ilişkileri ast-üst açısından baskın ideolojiyle tasarlamamış olabilir; fakat kadın-erkek ilişkisi yönünden filmin yoğun şekilde ataerkilliği yeniden ürettiği söylenebilir. Böylece ataerkil toplum düzenli ve olması gereken şekilde; kadınların ve erkeklerin yerlerini bildiği, toplumca sapkın sayılan cinsel tercihlere ise firsat verilmeyen bir alan olarak yeniden üretilir.

Filmin öyküsü kadar olay örgüsünde de baskın ideolojik mesajlara ulaşmak mümkün olmuştur. $\mathrm{Bu}$ açıdan ilk göze çarpanın, filmdeki şiddet ve cezalar 
aracılığıyla yeniden ürettiği değerler olduğu söylenebilir. Şiddet içerikli suç eylemleri anlatının geneline yayılmış durumdadır; fakat bu şiddetin uygulayıcıları muhakkak cezalandırılır. Filmde din, devletten çok daha büyük bir ceza kurumu olarak sunulur. Devletin bazı suçluları cezalandırdığı söylemlerine rastlanılan anlatıda, seyirciye en büyük cezalandırıcının Allah olduğu hatırlatılır. Ceza ise bir öte dünyada değil, yaşanılan dünyada gerçekleşir ve oldukça acı vericidir. Dolayısıyla suç ve cezaya karşı değerler, devlet ve daha üstünde din aracılığıyla yeniden üretilmiş olur. Filmdeki bu ideolojik tavır, 2000 sonrası Türk toplumunun yoğunlaşan muhafazakâr yapısına uygun gözükmektedir.

Filmin temellendiği suç eylemlerinin geçtiği mekânlar, suçun nasıl algılanması gerektiği konusunda seyircide bir gerçeklik oluşturması açısından önemlidir. Filmin ilk olarak Teo Bar mekânını yoğun bir suç ve şiddet alanına dönüştürdüğü görülür. Mekânın kana, cansız bedenlere, dağınık ve kırık eşyalara sahip bir yapıya büründürülmesi, suçun bu tip mekânlarda gerçekleşme ihtimalinin yoğunluğuna vurgu yapar. Yine de Teo Bar dışındaki mekânlarda gerçekleşen suç eylemlerinin gündüz vaktine konumlandırılması, anlatının geleneksel suç algısından uzak olduğunu destekler. Böylece "suç, gece işidir" gerçekliği, yerini "insanlar günün her anı suça karşı tedbirli olmalıdır" gerçekliğine bırakır. Buna rağmen, filmde toplumsal değerlere daha uygun olarak, suçun kamudan uzak, 1Ssız yerlerde işlenmesine izin verildiği anlaşılır. Dolayısıyla filmde asıl hesaplaşma mekânının depo olması şaşırtıcı değildir.

Kabadayı'daki bazı teknik kodların suç ve suçlu hakkındaki algıyı yeniden ürettiği söylenebilir. Film ideolojik bir aktarım arac1 olarak düşünüldüğünde, teknik kodlardan kurgunun önemi ortaya çıkar. Örneğin, yüzük, tespih ve silah gibi nesnelerin ayrıntı planına yapılan kesmeler, kabadayılığa ait kodları bünyesinde barındırırken, Teo Bar'daki yoğun suç sahnesine yapılan flashback, suçun acı ve gerilimli gösterir. $\mathrm{Bu}$ gösterimde kamera kullanımı önemlidir. Kameranın anlatı boyunca nesnel açıda kullanılması, seyirciyi suçlu karakterlerle kurulacak özdeşleşmeden uzaklaştırır. Kameranın bakış açısı, seyirciye mafya-kabadayı karşıtlığında kimin yanında olması gerektiğini hatırlatır. Bakış açısı, 'iyi' olarak kodlanan kabadayının yanında olunmasına hizmet ederken, yavaş kamera hareketleri suçun 'kötü' bir eylem olduğu ideolojisini destekler.

Özetle, Kabadayı'nın öykü ve olay örgüsüne sirayet eden tüm bu ideolojik yapılanmaların aile, devlet, din gibi kurumların ya da adalet, ahlak, delikanlılık, ataerkillik gibi toplumsal değerlerin yeniden üretilmesine hizmet ettiği söylenebilir. Film, suçlunun nasıl algılanması gerektiğini, suçun ac1 verici yönünü, devlet, din ve ailenin önemini, ataerkilliğin en ideal düzen olduğunu, polisin ve yasaların gerekliliğini ve cezanın muhakkak çekileceğini göstermektedir. Son olarak, suçluların din, devlet ve aile karşısındaki acizliğinin, seyircinin de bu kurumlar karşısında 'evcilleşmesine' hizmet ettiği söylenebilir.

\section{Kaynakça}

Abisel, N. (1995). Popüler sinema ve türler. İstanbul: Alan.

Adorno, W. T. \& Horkheimer, M. (2010). Aydinlanmanın diyalektiği. (N. Ülner \& E. Ö. Karadoğan, çev.). İstanbul: Kabalc1.

Baudrillard, J. (2011a). Simgesel değiş tokuş ve ölüm. (O. Adanır, çev.). İstanbul: Boğaziçi Üniversitesi.

Baudrillard, J. (2011b). Simülakrlar ve simülasyon. (O. Adanır, çev.). Ankara: Doğu Batı.

Benyahia, C. S. (2014). Suç. (A. Birsen, çev.). İstanbul: Kolektif.

Borde, R. \& Chaumeton, E. (2006). Towards a definition of film noir. A. Silver \& J. Ursini (Ed.), Film noir reader. New Jesey: Limelight.

Büyükdüvenci, S. \& Öztürk, S. R. (2007). Yeni Türk sinemasında estetik arayışı. Felsefe Dünyası Dergisi, 46, 4549.

Clarens, C. (1979). Crime movies: An illustrated history. New York: W. W. Norton.

Comolli, J. L. \& Narboni, J. (2010). Sinema/ideoloji/eleştiri. (M. Temiztaş, çev.). S. Büker \& Y. G. Topçu (Ed.), Sinema: tarih, kuram, eleştiri. İstanbul: Kırmızı Kedi.

Corrigan, T. (2011). Film eleştirisi. (A. Gürata, çev.). Ankara: Dipnot.

Demirbaş, T. (2012). Kriminoloji. Ankara: Seçkin. 
Dixon, W. W. (2013). Precursors to film noir. A. Spicer \& H. Hanson (Ed.), A Companion to film noir. Oxford: Blackwell.

Dönmezer, S. (1994). Kriminoloji. İstanbul: Beta.

Foucault, M. (2012). İktidarın gözü. (I. Ergüden, çev.). İstanbul: Ayrint1.

Grant, K. B. (2011). Shadows of doubt: Negotiations of masculinity in American genre films. Detroit: Wayne State University.

Kakınç, D. T. (1993). 100 filmde başlangıçtan günümüze gangster filmleri. Ankara: Bilgi.

Kırel, S. (2012). Kültürel çalışmalar ve sinema. İstanbul: Kırmızı Kedi.

Klinger, B. (2010). Sinema/ideoloji/eleştiri üzerine: İlerici metin. (Y. G. Topçu, çev.). S. Büker \& Y. G. Topçu (Ed.), Sinema: Tarih, kuram, eleştiri. İstanbul: Kırmızı Kedi.

Krutnik, F. (2001). In a lonely street: Film noir, genre, masculanity. Taylor \& Francis E-Library.

Leitch, T. (2002). Crime films: Genres in American cinema. Cambridge: Cambridge University.

Maltby, R. (2008). Sansür ve kendi kendini düzenleme. (A. Fethi, çev.). G. N. Smith (Ed.), Dünya sinema tarihi. İstanbul: Kabalc1.

Marks, K. \& Engels, F. (2003). Alman İdeolojisi. Eriş Yayınları: E-kitap.

Marks, K. (1998). Artı-değer teorileri: Birinci kitap. (Y. Fincanc1). Ankara: Sol.

McLellan, D. (2012). İdeoloji. (Barış Yıldırım, çev.). İstanbul: İstanbul Bilgi Üniversitesi.

Monaco, J. (2010). Bir film nasıl okunur? (E. Yılmaz, çev.). İstanbul: Oğlak.

\section{Notlar}

i Türk Sinemasının Kilometre Taşları, http://www.tsa.org.tr/tr/sayfa/timeline

ii Türk Filmleri Seyirci Rekoru - İlk 100 (1989'dan Günümüze), https://boxofficeturkiye.com/tumzaman/?tm=1989tr
Oskay, Ü. (1980). Popüler kültür açısından ideoloji kavramı ilişkin yeni yaklaşımlar. Ankara Üniversitesi Siyasi Bilgiler Fakültesi Dergisi, 35(1), 197-253.

Özden, Z. (2004). Film eleştirisi. Ankara: İmge.

Pearson, R. (2008). Sinemanın ilk dönemi. (A. Fethi, çev.). G. N. Smith (Ed.), Dünya sinema tarihi. İstanbul: Kabalc1.

Pezzella, M. (2006). Sinemada estetik. (F. Demir, çev.). Ankara: Dost Kitabevi.

Roloff, B. \& Seeßlen, G. (1997). Cinayet sineması. (S. Kaya \& S. N. Kaya, çev.). İstanbul: Alan.

Ryan, M. \& Kellner, D. (2010). Politik kamera. (E. Özsayar, çev.). İstanbul: Ayrıntı.

Scognamillo, G. (1997). Dünya sinema sanayii. İstanbul: Timaş.

Süalp, Z. T. A. (2009). Yabanıl, dışarlıklı ve lümpen "hiçlik" kutsamaları seyrelmiş toplumsallık ve yükselen faşizan hallerin "post”lar zaman1. D. Derman (Der.), Türk film araştırmalarında yeni yönelimler 8: Sinema ve politika. İstanbul: Bağlam.

Therborn, G. (1989). Iktidarın ideolojisi ve ideolojinin iktidart. (İ. Cüre, çev.). İstanbul: İletişim.

Türk Filmleri Seyirci Rekoru- İlk 100 (1989’dan günümüze). https://boxofficeturkiye.com/tumzaman/?tm=1989tr adresinden erişilmiştir.

Türk Sinemasının Kilometre Taşları. http://www.tsa.org.tr/tr/sayfa/timeline adresinden erişilmiştir.

Williams, R. (2012). Anahtar sözcükler. (Savaş Kılıç, çev.). İstanbul: İletişim.

Yücel, V. (2014). Kahramanın yolculuğu: Mitik erkeklik ve suç draması. İstanbul: İstanbul Bilgi Üniversitesi 